\title{
小览心臓外科への提言
}

\author{
北里大学医学部心臟血管外科
}

宮地鑑

\section{My Proposal for Pediatric Cardiovascular Surgery in Japan}

\author{
Kagami Miyaji \\ Department of Cardivascular Surgery, Kitasato University School of Medicine, Sagamihara, Japan
}

\section{"Attending surgeon"}

これはアメリカやカナダなど北米で使われている言葉で, 英連邦では Consultant といわれているものです. Attending は日本語では主治医とか担当医とでも訳すのがいいのでしょうか. 独立して責任を持って治療や手術を行 うことができる医師で, 多くは専門医資格を有しています。外科系診療科では, 同時に 2 人の Attending が手術に入 ることはほとんどありません. Attending surgeon おのおのが内科や小児科から直接患者を紹介されて執刀します. Resident やFellow のいない一般病院では, Surgical Assistant(Physician’s assistant)と手術をします. 何があっても誰も 助けてくれない状況で, 全責任を負って手術をしておりますので, 彼らの精神力はかなりのものです. 常に冷静で, 手術中に大声で怒鳴ったりすることもなく, パニックになる姿は私自身 2 年間のアメリカ留学中, 一度も見たこと がありません．ある Attending surgeonにどうして想定外の困難な状況でも冷静でいられるのか質問したことがあり ます. 彼は「自分が取り乱してパニックになって誰が患者を救うことができるのか, 手術室内のリーダーとして状況 を完全に掌握するように冷静になることが肝要で, それができなければ, Attending 失格である」と答えました。 Attending がたびたびパニックになっていたら, パラメディカルも麻酔科医も誰もついてこなくなり, 彼自身の評価 は下がり, 職を失う可能性さえあります。

欧米の施設では, 必ず複数(最低でも 2 人以上)の Attending や Consultant がいます. 各施設の症例数が日本に比して, はるかに多いからだと思われているかもしれませんが, 実はそれだけではありません，アメリカでは国土の広大さ から, 小児心臟外科施設の集約化が完全ではありません. 年間手術症例数が 100 例そこそこの小児病院がかなりの数, 存在します，その施設でも 2 人以上の Attending がいることがほとんどです.なぜでしょうか？ 理由は 2 考えら れます. 1 つは, 危機管理上の問題です.もし，1 人 Chief Attending 体制(多くの日本の施設はこの体制)で, 彼・彼女 に事故があった場合, 病院機能は完全に麻疩してしまいます. 2 人以上 Attending がいれば, 急に 1 人が久けても, も う 1 人が対応することで, 医療崩壊を防ぐことが可能です。もう 1 つは休養の問題です. 交代で休暇をとることで, 家庭を犠牲にすることなく, 幸福な生活が扔くれます。また, 学会参加などの学術的な活動も可能となり, 心臓外科 医自身のレベルアップにつながります．

チーフでない Attending は経験を積んで成果を上げることで, さらに大きな施設の Attending やチーフとして採用 されていきます. その結果として, 症例数の多い一流の施設のチーフやAttending は優秀で, 手術成績は常にトップ クラスに維持されていきます.

\section{私の提言}

日本では, 多くの施設が 1 人 Attending surgeon 体制です。これは先述のように, 危機管理上, 問題であるとともに, 心藏外科医に大きな精神的・肉体的負担をかけていることを小児循環器の先生方に知っていただきたいと思います。

2010 年に主任教授に就任して以来, 北里大学心臟血管外科では, 複数 Attending surgeon 制を導入しました. 成人心 臓外科に准教授 (42 歳) ・講師 (41 歳) の 2 名の Attending を置き, 小児心臟外科にも, 私と岡徳彦診療准教授 (41 歳) 
の 2 名, 計 4 名の Attending surgeonで, 2013 年は 270 例以上の心臓大血管手術を施行しました。原則として Attending は独立して, 若い修練医や研修医と手術を行っております. 年 $2 \sim 3$ 回の国際学会や小児循環器学会を含 む国内主要学会に, 手術を止めず, 参加することが可能となり, 循環器内科や小児科の石井正浩教授にご迷惑をかけ ることもなくなりました

私は, ある程度の症例数のある小児心臟外科施設(たとえば 100 例以上)では, 複数 Attending 制が, 危機管理上も 労務環境上も望ましいと考えます. 100 例程度の手術症例数で, 2 人のAttending では手術成績・技能が維持できな いのではないかと危惧される方もいらっしゃるかもしれません. 成人の冠動脈バイパス手術では, 心臟外科医 1 人 あたり欧米よりはるかに少ない手術症例数 (おそらく $1 / 3$ から $1 / 2)$ にもかかわらず, また患者の体格も小さく冠動脈 も細く手術の難易度が高いにもかかわらず, 手術成績は欧米よりも優れています。これは, 日本独特の一人ひとりの 患者をじっくりと大切に術前・術後管理してゆくシステムと, まじめで几帳面な国民性によるところが大きいと思 われます。この日本の優れたシステム・国民性と欧米型の合理主義を併用することで, 手術成績を安定させつつ, 時 間はかかるかもしれませんが, 確実に将来のチーフの育成が可能となると思います．

このためには, 小児循環器医の理解と協力が必須であります。アメリカでもヨーロッパでも複数 Attending や Consultant がいれば, 必ずしも同等の手術技能・成績ではありません. 患者家族も小巟循環器医も自分の子供や患者 は経験豊富な部長やチーフに執刀してもらいたいと思うのが当然です。しかし，ここはひとつ，もう 1 人の若い Attending にぜひ執刀する機会を与えていただきたいと思います。私自身, アメリカから帰国して2000年に神奈川県 立こども医療センターに医長として赴任し, 当時の康井制洋循環器科部長 (現総長) と長田信洋心臟血管外科部長 (現 沖縄県立こども医療センター小児心臓血管外科部長)のおかげで多くの手術を執刀する機会をいただいたからこそ, 今日の北里大学での立場があるのだと思います. 近年, 手術成績の向上により, より完璧な手術が要求され, ささい な失敗も許されない状況となっています。それでも，患者を紹介してくださる小児循環器の先生方には，若い Attending surgeonの成長を暖かく見守り, Fallot 四徴症や Glenn・Fontan 手術などをはじめとする定型的な手術や比 較的リスクの少ない新生児開心術症例 (大動脈縮窄複合や I 型完全大血管転位など)を任せていただきたいと思いま す，そうすることが次世代の優秀な小児心臟外科医を作り，日本の小児心臟外科のレベルを維持・発展させ，結果と

して社会に大きく貢献することになるからです，

小児心臟外科医, 特にチーフ自身も意識を変える必要があります。臓外科では成人心臓外科をはじめ, 学閥によ る関連病院化が行われてきました。 小児心臟外科でも同様に, 大学医局による小児心臟外科施設の関連化が行われ ております。一方, 心臟外科医の希望者が年々減少する中, 小児心臟外科医希望者の激減は絶望的ですらあります。 この少ない将来のAttending 候補者を日本全体で育成することが急務であり，その意味でも，学閥を超えた Congenital Heart Surgeons' Society in Japan が結成されたことは今後の若手修練システムの構築や Attending surgeon を 含めた人事交流の活発化など大いに期待できると思います。 